\title{
A home-based clothing manufacturing: the owner and the business
}

\author{
Annette M van Aardt and J Kroon
}

\begin{abstract}
OPSOMMING
Die kompleksiteit en koste verbonde aan die gebruik van nywerheidspersele en besigheidsentrums, beter kommunikasie as gevolg van die elektroniese revolusie en die gebruik van rekenaars, die Internet en faksmasjiene, afskaling van poste en ' $n$ behoefte aan beter diens, het gelei tot die onlangse oplewing in tuisondernemings. Die versoenbaarheid van sulke tuisondernemings en gesinsverantwoordelikhede het verder daartoe aanleiding gegee dat baie vroue hulle tot klerevervaardiging tuis gewend het.
\end{abstract}

Die doel van die studie was eerstens om ' $n$ verkennende, beskrywende ondersoek te loods na die gesinsomgewing waar daar kinders is asook die demografiese eienskappe in klerevervaardigingsondernemings tuis en tweedens om aspekte van die aanvang en funksionering van hierdie ondernemings te beskryf.

'n Gestruktureerde vraelys is by wyse van onderhoudvoering deur ' $n$ gerieflikheidsteekproef van 50 vroue in klerevervaardigingsondernemings tuis voltooi.

Die resultate het aangedui dat byna $75 \%$ van die respondente getroud was. Die meeste van hulle was ouer as $\mathbf{3 0}$ jaar, en $34 \%$ se jongste kinders was 19 jaar of ouer. Twee derdes het ' $n$ kwalifikasie van matriek of laer behaal, en een derde het tersiêre kwalifikasies verwerf. Die meeste van hulle $(86 \%)$ het geen formele bestuursopleiding ontvang nie, maar $62 \%$ het spesifieke opleiding op een of ander gebied van klerevervaardiging ondergaan. Die helfte van die respondente was 'n middelkind in hul gesinne, $56 \%$ se ouers het hulle eie sakeondernemings gehad, en $\mathbf{8 0} \%$ was van die middel sosiale klas afkomstig.

Tipiese suksesfaktore in die literatuur wat in verband met klein ondernemings genoem word, is in hierdie studie ondersoek. Faktore soos goeie diens en menseverhoudings, produkte van hoë gehalte, selfdissipline en werkywer is as die belangrikste suksesfaktore in hierdie studiepopulasie geïdentifiseer. Enkele probleme wat genoem is, het die verkryging van kapitaal en krediet, ' $n$ balans tussen gesinsverpligtinge en ondernemingseise, rekordhouding en finansiële bestuur ingesluit.
Daar is tot die gevolgtrekking gekom dat tuisklerevervaardigingsondernemings besondere voordele vir vroue met gesinne inhou. Tuisondernemings is meer lewensvatbaar weens die klein aanvangskapitaal wat vereis word asook die lae bokoste. $\mathrm{Na}$ aanleiding van die bevindinge is voorgestel dat vroue in tuisklerevervaardigingsondernemings meer formele bestuursen klerebedryfsopleiding behoort te ontvang. Die potensiaal vir tuisondernemings in SuidAfrika is nog nie ten volle benut nie en bied dus goeie geleenthede vir werkskepping.

- Prof AM van Aardt

Department of Nutrition \& Family Ecology, PU for CHE - Prof J Kroon

Department of Business Management, PU for CHE

\section{INTRODUCTION}

The recent revival of home-based businesses, also referred to as cottage industries, was brought about by various factors, for example the complexity and cost of using industrial parks and business complexes, the electronic revolution and enhanced communication through the use of computers, the Internet and fax machines, massive lay-offs by a wide spectrum of employers in South Africa and the demand for better service (Ehlers, 1998; Lambling \& Kuehl, 1997:52). Additional sound reasons for the tremendous growth in home-based businesses since the eighties, include the following:

- Continuing downsizing of corporations, accompanied by the above-mentioned technological developments which make working from home as productive and efficient as working from an office

- Creative and financial freedom (Watts, 1994)

- Women in home-based enterprises have more control over their lives and are able to spend more time with their families (Beech, 1997)

- Little initial capital is needed

- High overhead costs are eliminated

- The owners can be on the premises around the 
clock and are able to work any hours they want (Beech, 1997).

The eyes of millions of unemployed and underemployed South Africans have been on the Government of National Unity's attempts to create jobs and promote economic empowerment. The government has identified small, medium and microenterprises (SMMEs) as a medium to address the economic challenges in this country. It is believed that these SMMEs constitute the last gold mine for creating wealth for many citizens (Mentoor, 1996:1). Homebased businesses may, according to the White Paper on a national strategy for the development and promotion of small business in South Africa (1995:9-10), be classified as microenterprises.

Women consequently cannot be ignored as contemporary and future small-business owners. Women form more than half of the world population. Businesses owned by women are the fastest growing small enterprises in the USA. Women own approximately one third of all businesses, $50 \%$ of all retail businesses, and $70 \%$ of all service businesses in the USA (Sitterly, 1994:1). Traditionally, women employed in big businesses often encountered obstacles to career advancement due to discrimination and organisational dynamics (Buttner \& Moore, 1997).

In South Africa many women were marginalised in the past in terms of access to further education, technical skills and general business exposure, with a consequent lack of business confidence (Ndu, 1997:139). Due to the fact that price increases often exceed salary increases in South Africa, many women urgently need additional incomes to sustain their households. This suggests turning away from job incomes to other alternatives.

Home-based business alternatives have become an especially attractive proposition for women, as they still assume a disproportionate share in maintaining a home life. Women in home-based businesses are more flexible in managing their dual responsibilities and balancing their work and families (Alderman \& Cheney, 1997). Lately, women business owners have been playing for higher stakes and many are discoverng that there is no glass ceiling in an own business (Pofeldt, 1997).

\section{PROBLEM STATEMENT}

Since the late eighties, the South African clothing industry has changed dramatically from a few large clothing manufacturers and wholesalers to more and smaller manufacturers and retailers (Clofed, 1996:117). With fewer jobs available in the formal sector, and the South African clothing industry in difficulties, small clothing-manufacturing home-based businesses seem to offer an opportunity to generate income. However, there is a general lack of information on women in home-based clothing manufacturing and how they manage their businesses. A number of questions should be attended to in South Africa to encourage these women to tear down barriers and emerge as successful players on the home-based business scene.

\section{GOAL}

The goal was to undertake an exploratory, descriptive study, firstly to describe the childhood family environment and demographic factors in home-based clothing manufacturing businesses, and secondly to describe the start-up and functioning of these home-based businesses.

\section{RESEARCH FRAMEWORK}

The research framework used for this study is illustrated in Figure 1. The concepts of a home-based business and the home-based business owner are described first.

\section{Home-based businesses}

These businesses are defined as full-time or part-time, profit-oriented businesses, operated in or from a self-employed individual's residence or surrounding buildings. Roberts and Chrisman (1996) present the above definition as cited by various authors, but point out that numerous definition categories are possible. Broader and more inclusive definitions specify that the owners of homebased businessess do not require transport to a primary work location, are employed at home and work at home more than $50 \%$ of the number of hours available for work.

Home-based business owner The definition of an entrepreneur by Hatten (1997:31), Hisrich and Peters (1998:9) and others, may also be applied to home-based business owners, as they identify a business opportunity, take some calculated risks, apply general management principles and have performance intentions. Running a business from home requires the same drive and skills as those demanded in a formal business environment, perhaps more so (Ehlers, 1998).

Regarding the research framework, two main aspects of the home-based business were investigated, namely the owner and the business. Knowledgeable authors highlight various themes as important factors in the success of small businesses. As the researchers regard the home-based business as a specific segment of small businesses, these factors were considered appropriate for use as variables in a study of home-based business owners and their businesses. The researchers conducted an in-depth literature study and identified two main themes associated with the successful establishment and running of a small business:

- With reference to the business owner. Childhood family environment factors (Hisrich \& Peters, 1998:71) and demographic factors (Longenecker et al, 1997:12-13; Hisrich \& Peters, 1998:71-72; 


\begin{tabular}{|c|c|c|}
\hline \multicolumn{2}{|c|}{ THE HOME-BASED BUSINESS OWNER } & \multirow{2}{*}{$\begin{array}{c}\begin{array}{c}\text { THE HOME BASED } \\
\text { BUSINESS }\end{array} \\
\begin{array}{c}\text { Start-up and } \\
\text { functioning }\end{array}\end{array}$} \\
\hline $\begin{array}{l}\text { Childhood family } \\
\text { environment }\end{array}$ & Demographic factors & \\
\hline $\begin{array}{l}\text { Birth order } \\
\text { - Entrepreneurial parents } \\
\text { - Socioeconomic status }\end{array}$ & $\begin{array}{l}\text { Family situation } \\
\text { - Marital status } \\
\text { - Age } \\
\text { - Language } \\
\text { - Children } \\
\text { Qualifications and } \\
\text { experience } \\
\text { - Academic qualifications } \\
\text { - Formal business training } \\
\text { - Business experience }\end{array}$ & $\begin{array}{l}\text { - Origin } \\
\text { - Reason for starting } \\
\text { - Capital } \\
\text { - Form of business } \\
\text { - Age of business } \\
\text { - Eearly turnover } \\
\text { - Eenployees } \\
\text { - Target of work day } \\
\text { - Business success } \\
\text { factors }\end{array}$ \\
\hline Selected characteristic & $\begin{array}{c}\text { home-based business ow } \\
\text { turing businesses }\end{array}$ & eir clothing manufac \\
\hline
\end{tabular}

FIGURE 1: $\quad$ RESEARCH FRAMEWORK

Kuratko \& Hodgetts, 1995:647; Zimmerer \& Scarborough, 1996:14) were the two main variables discussed in connection with the home-based business owner.

- With reference to the business. According to various authors (Kuratko \& Hodgetts, 1995:531; Anderson \& Woodcock, 1996:206-207; Moorman \& Halloran, 1993:4; Beech, 1997; Alderman \& Cheney, 1997), the start-up and functioning of a business are important in determining its overall performance.

The main themes and concepts with reference to the owner and the home-based business, as illustrated in the research framework (see Figure 1), will be integrated in the discussion of the results.

\section{RESEARCH METHOD}

\section{Questionnaire}

Very little research data on small businesses in South Africa could be found, and none at all on women in home-based clothing manufacturing. A structured questionnaire which correlates with the research framework was compiled. This questionnaire was tested in a trial run during which three female homebased business owners were interviewed. Vague and ambiguous questions that could lead to misconceptions or a halo effect were identified and rectified. The three female respondents were encouraged to give an honest opinion, as they did not participate in the final investigation. The questions corresponded with the research framework. The following variables were investigated in the questionnaire:

\section{A The home-based business owner}

- The respondents were asked to list the birth order of the children in the family environment, whether one or both parents were self-employed, and the socioeconomic class in which the children were being raised.

- Demographic factors pertaining to the family were investigated by means of questions on marital status, age, home language and the number of children in different age groups.

- Qualifications and experience were investigated by asking whether the respondents had obtained a senior certificate, a college or technikon qualification and/or a university degree, and at which level. They were also asked to indicate their formal business training as none, little, average or a lot, and where applicable to identify the specific training they had received. The respondents were asked how many years of business experience they had in clothing retail, wholesale and manufacturing, and to mention any other business experience.

\section{B The business}

Questions were asked about the origin (founded 
personally or bought), the reasons for starting the business (be their own boss, found it a challenge, wanted to earn money, and/or deemed it compatible with family life), the source of capital (own capital or loan), the form of business (sole proprietorship, partnership, close corporation, other), the age of the business according to the categories used by Kuratko and Hodgetts (1995:648) and Timmons (1994:10), yearly turnover, number of employees (0 to 10+), length of work day ( $<8$ hours, $8-12$ hours and $>12$ hours), the target market, and problems they encountered with regard to the business (obtaining initial capital and credit, balance between family needs and business, bookkeeping and financial management, advertising and sales promotion, and/or cash-flow problems).

Two authors (Dollinger, 1995:55; Moolman, 1992:11) have named several problems which occur generally in small businesses. The respondents were asked to describe the extent to which they experienced these problems on a three-point scale (no, moderate and big extent). An open-ended question asked what they deemed to be factors that contributed to the success of their businesses.

The preliminary questionnaire was tested on three home-based clothing manufacturing business owners. A few adjustments were subsequently made, and three open-ended questions were added to include aspects which these business owners deemed to be important factors in the viability of their businesses (see Table 5).

\section{Sample}

A convenience sample incorporated 50 women in Potchefstroom and on the East Rand who owned home-based clothing manufacturing businesses. The snowball sampling method was used. These two locations were chosen on economic grounds and were within easy reach of the researchers. A few respondents known to the researchers referred them to other home-based business owners who could qualify as respondents. Fifty-six eligible respondents were subsequently identified. They were contacted telephonically to make appointments for interviews. Fifty of these business owners were willing to take part in the study.

Huysamen (1994:46) points out that there is nothing wrong with conducting research on subjects in an easily available population, as long as the researcher does not generalise the results for the entire population. This was not the intention of this study.

\section{Data collection}

The questionnaires were completed during an interview with each respondent, and this took about half an hour. The structured questionnaire was mainly aimed at collecting quantitative data. The factors mentioned by the respondents in addition to those on problems in the business, were incorporated in the results (see Table 5).

\section{Reliability and validity}

Reliability could not be determined by means of the most commonly used methods, for example testing/ retesting, alternate forms, split-half and internal consistency methods, due to the nature of the measuring instrument and the practical obstacle of administering the interview a second time, as the respondents were extremely busy. However, the researchers maintained interrater or intertester reliability by preventing unreliability due to accidental, inconsistent behaviour on the part of the individual who conducted the interviews (suggested by Huysamen, 1994:121 and Babbie, 1995:126). One interviewer conducted all the interviews, so a consistent rating was maintained. This interviewer was well trained to be brief, to explain the purpose of the study, to inspire a trusting relationship, not to invade the privacy of the respondents, and to keep strictly to the structure of the questionnaire (suggested by Murphy \& Davidshofer, 1994:24-26; 360-362 and Huysamen, 1994:144).

Validity in this study was assessed by investigating content and construct validity, which both represent approaches to determining whether a test provides a valid measure of specific attributes (Murphy \& Davidshofer, 1994:107). Content validity refers to the degree to which a measure covers the range of meanings included in the concept (Babbie, 1995:128).

Murphy and Davidshofer's (1994:111) procedure for assessing content validity was followed in this study. This procedure consists of three steps, namely describing the content domain (by undertaking a literature study of factors that play a role in the success of small businesses), determining areas of the content domain that are measured by each test item (by making sure that each variable in the research framework was tested by at least one question in the questionnaire), and comparing the structure of the test with the structure of the content domain, which in this study is represented by the research framework.

Another precaution was to ensure that the test items were within the boundaries of the domain. Three women who were home-based business owners and who did not take part in the final study, were asked to comment on the questionnaire in terms of the applicability of each test item to the factors that play a role in the success of a small business. Construct validity is based on the logical relationships between variables. No factor analysis could be conducted in this study to determine such relationships, as the measuring instrument did not include a scale. The fact that the test items were grouped together according to general trends in the literature, indicating factors that play a role in the success of small businesses, portrays a certain amount of construct validity.

\section{Statistical analysis}

Due to the very limited amount of information available on women who own home-based businesses in South Africa, especially with reference to clothing manufacturing, this was an exploratory study to form a 
TABLE 1: CHILDHOOD FAMILY ENVIRONMENT

\begin{tabular}{|l|l|c|c|}
\hline \multicolumn{2}{|l|}{} & $\mathrm{N}(\%)$ & Effect size w \\
\hline Birth order & First-born & $13(26 \%)$ & \\
& Middle child & $25(50 \%)$ & $0,66^{*}$ \\
& Youngest & $10(20 \%)$ & 0,12 \\
\hline Self-employed parents & Only child & $2(4 \%)$ & $0,99^{\star}$ \\
\hline Socio-economic status & Yes & $28(56 \%)$ & 0 \\
& No & $22(44 \%)$ & $0(12 \%)$ \\
\hline
\end{tabular}

base for further research.

Statistical analyses consisted mainly of frequency calculations of all the variables. Standard deviations as a measure of variance were determined to indicate agreement or disagreement between the respondents. For questions offering more than one response category such as Likert-scale type of questions, average values were calculated for each item in the question. This made it possible to determine a ranking for each item, so that tendencies could be identified.

A one-dimensional chi-square analysis (Steyn et al, 1994:551; Cohen, 1988:221) was performed on the data in Tables 1 to 4 when only one response per variable was required. W-values (Cohen, 1988:223) were computed from the chi-square values that were obtained, to indicate the strength of the effect in the distribution of responses. According to Cohen (1988:224-225), $\mathbf{w}=0,50$ indicates a large effect size, $\mathbf{w}=0,30$ indicates a medium effect size and $\mathbf{w}=0,10$ indicates a small effect size. A large effect size $(\mathbf{w}=$ $0,50)$ means that the distribution is not uniform. The larger the effect size $\mathbf{w}$, the less uniform the distribution of responses between the response categories.

For the purposes of this study, $\mathbf{w}>0,5$ implies that the distribution of responses between the various response categories is strongly non-uniform.

\section{RESULTS AND DISCUSSION}

The results are presented according to the research framework. The findings are compared with the research findings of empirical studies in the USA on the background and profile of small-business people and home-based business owners and their businesses.

\section{The home-based business owner}

Childhood family environment According to Hisrich and Peters (1998:70), birth order, whether the business people had self-employed parents or not, and the socioeconomic status of the business people during childhood play a role in promoting selfemployment. The data regarding these variables are depicted in Table 1.
Birth order Being the first-born or an only child is postulated to result in a child with more selfconfidence, due to the special attention it received. In a national study in the USA it was found that $50 \%$ of 408 female business owners were first-born children (Hisrich \& Peters, 1998:71).

The results in Table 1 indicate that half of the respondents, namely $25(50 \%)$, were middle children in their families, and that $13(26 \%)$ were first-born children. The effect size $w=0,66$ indicates a large effect size, and confirms that the distribution of responses was not uniform. In many studies of male and female business people, however, the first-born effect has not been present and the researchers suggest further research in this regard (Hisrich \& Peters, 1998:71).

\section{Self-employed parents}

In this study, just more than half, namely $28(56 \%)$ respondents, had self-employed parents. There is no strong evidence of self-employed fathers in this study, and this is confirmed by the small $\mathbf{w}$-value. This finding does not correspond with that of Hisrich and Peters (1998:71) who concluded that the independent nature and flexibility of self-employment exemplified by the father are ingrained at an early age and could possibly influence the children not to even think of going to work for anybody else.

\section{Socio-economic status}

Female business owners tend to grow up in middle to upper-class environments, where families are relatively child-centred and supportive of their children. The majority of the respondents in this study, namely $40(80 \%)$, as confirmed by the large effect size of $\mathbf{w}=0,99$, stemmed from the middle socioeconomic class. This finding corresponds with the finding of Hisrich and Peters (1998:71) who said that female business owners tend to grow up in middle to upper-class environments.

Demographic factors The demographic factors that are often reported in connection with selfemployed people, are family situation (marital status, age and children), qualifications and experience. The demographic data for these respondents are presented in Table 2. 
TABLE 2: DEMOGRAPHIC FACTORS OF HOME-BASED BUSINESS OWNERS

\begin{tabular}{|c|c|c|c|c|}
\hline Family situation & & & $\mathrm{N}(\%)$ & $\begin{array}{c}\text { Effect size } \\
\mathbf{w}\end{array}$ \\
\hline Marital status & \multicolumn{2}{|c|}{$\begin{array}{l}\text { Married } \\
\text { Divorced } \\
\text { Never married } \\
\text { Widow }\end{array}$} & $\begin{array}{r}36(72 \%) \\
7(14 \%) \\
4(8 \%) \\
3(6 \%)\end{array}$ & 1,09 \\
\hline Age of business owner & \multicolumn{2}{|c|}{$\begin{array}{l}18-29 \text { years } \\
30-39 \\
40-49 \\
50-59 \\
60 \text { and over }\end{array}$} & $\begin{array}{r}5(10 \%) \\
15(30 \%) \\
14(28 \%) \\
14(28 \%) \\
2(4 \%)\end{array}$ & 0,54 \\
\hline Language & \multicolumn{2}{|l|}{$\begin{array}{l}\text { Afrikaans } \\
\text { English }\end{array}$} & $\begin{array}{r}45(90 \%) \\
5(10 \%)\end{array}$ & 0,80 \\
\hline Age of youngest child & \multicolumn{2}{|c|}{$\begin{array}{l}\text { No children } \\
0-6 \text { years } \\
7-13 \\
14-18 \\
\text { Over } 18\end{array}$} & $\begin{array}{r}5(10 \%) \\
9(18 \%) \\
9(18 \%) \\
10(20 \%) \\
17(34 \%)\end{array}$ & 0,39 \\
\hline \multicolumn{5}{|l|}{ Qualifications and experience } \\
\hline Academic qualifications & \multicolumn{2}{|c|}{$\begin{array}{l}\text { Grade } 12 \text { or lower } \\
\text { College } \\
\text { Technikon } \\
\text { First university degree } \\
\text { Post graduate degree }\end{array}$} & $\begin{array}{r}33(66 \%) \\
4(8 \%) \\
2(4 \%) \\
7(14 \%) \\
4(8 \%)\end{array}$ & 1,16 \\
\hline Formal business training & \multicolumn{2}{|l|}{\begin{tabular}{|l} 
None \\
Little \\
Moderate \\
\end{tabular}} & $\begin{array}{r}43(86 \%) \\
3(6 \%) \\
4(8 \%)\end{array}$ & 1,05 \\
\hline $\begin{array}{ll}\text { Business experience } \\
\text { Type: } & \text { Retail } \\
& \text { Wholesale } \\
& \text { Manufacturing }\end{array}$ & $\begin{array}{l}\text { None } \\
40(80 \%) \\
47(94 \%) \\
43(86 \%)\end{array}$ & $\begin{array}{l}<5 y r \\
5(10 \%) \\
1(2 \%) \\
4(8 \%)\end{array}$ & $\begin{array}{l}>5 \mathrm{yr} . \\
5(10 \%) \\
2(4 \%) \\
3(6 \%)\end{array}$ & $\begin{array}{l}0,99 \\
1,29 \\
1,12\end{array}$ \\
\hline
\end{tabular}

\section{Family situation}

More than $50 \%$ of all women business owners are married and have children (Hisrich \& Brush, 1984; Bowen \& Hisrich, 1986; Scott, 1986). Compatibility with family commitments is given as one of the reasons why women start their own businesses, albeit not the main reason (Scott, 1986). Nearly three quarters of the respondents, namely $36(72 \%)$, were married. This corresponds with the national USA data according to which $71 \%$ of women business owners are married (Kuratko \& Hodgetts, 1995:647). The large effect size of $\mathbf{w}=$ 1,09 confirms the data.

The ideal age to start a business seems to lie somewhere between the late twenties and early forties, when there is a balance between preparatory experiences on the one hand and family obligations on the other (Longenecker et al, 1997:13). Hisrich and Peters (1998:72) set wider bounderies, saying that most business people start their business careers between the ages of 22 and 55 . In this study $15(30 \%)$ of the business owners were aged between 30 and 39 years, and equal groups of $14(28 \%)$ each were aged 40 to 49 and 50 to 59 years. The majority, confirmed by $\mathbf{w}=0,54$, fall in the age group 30 to 59 years, which broadly corresponds with the findings of Hisrich and Peters (1998:72).

With respect to language 45 (90\%) of these respondents ( $\mathbf{w}=0,80$, indicating a large effect), were Afrikaans-speaking. This could be ascribed to the sampling method, as the first few respondents identified by the researchers were Afrikaans-speaking, and they identified more Afrikaans-speaking respondents.

According to Erwee (1987), about half the number of South African female business owners have no dependent children. The age of the youngest child in this study is indicated in Table 2. According to the results, the biggest group, namely 17 (34\%), has children of 19 years and older. This indicates that about 
a third of the respondents had older children who were probably no longer dependent on them. The $\mathbf{w}$ value $=0,39$, indicating a medium effect size.

Qualifications and experience According to Longenecker et al (1997:12), education and experience are key elements in the success of most business people. Although the requirements vary with the nature and demands of a particular business, some know-how is needed.

Hisrich and Peters (1998:71) confirm the importance of education in the upbringing of business people, contrary to the belief in South Africa that business people do not need as much education as the general population. Anderson and Woodcock (1996:20) point out that individuals with high academic qualifications might find many of the tasks associated with running a business unsatisfying. In general, however, good education probably accounts for a high survival rate in business, although there are cases where education appears to have little effect.

Thirty-three $(66 \%)$ of the respondents in this study obtained matric or a lower school qualification, 6 $(12 \%)$ had college or technikon training, 7 (14\%) obtained a first university degree, and $4(8 \%)$ obtained a postgraduate degree. The results reveal that only about a third of the respondents had a tertiary education and the $\mathbf{w}$-value $=1,16$ indicates a large effect size. Ten of the respondents $(20 \%)$ studied fashion design or home economics during their tertiary training, $5(10 \%)$ studied in the educational field, and 2 $(4 \%)$ studied communication. The responses $(\mathbf{w}=$ $1,36)$ are strongly non-uniform.

With respect to formal business training women business owners experienced some disadvantages in the past. Research in the USA showed that few have degrees in business, engineering, science and mathematics. Although the number of female students in the above-mentioned schools increased significantly, both male and female business owners cited a need for training in the areas of finance, strategic planning, marketing and management. The ability to deal with people and to communicate effectively in written and spoken work is also an important requirement (Hisrich \& Peters, 1998:72).

Forty-three (86\%) of the respondents in this study had no formal business training, $3(6 \%)$ had a little, and 4 $(8 \%)$ had a moderate amount. The large effect size of $\mathbf{w}=1,05$ emphasises the finding that the majority of these respondents had received no formal business training.

Various authors (Kuratko \& Hodgetts, 1995:647; Zimmerer \& Scarborough, 1996:14; Timmons, 1994:200) point out that having relevant experience and appropriate skills for a particular business can dramatically improve the odds for success. The prospective business person should ideally have an adequate working knowledge of the physical operation of the business as well as the skill to manage the busi- ness'employees and to motivate them to perform better. If experience is lacking, the business person will have to learn while operating the business, and this might be more time and money-consuming than most can afford. On the other hand, according to Anderson and Woodcock (1996:20), a successful business person will need to do something new, in which case experience could be a disadvantage. Experience might lead to a "more of the same" approach, whereas business success requires change.

The respondents' experience in the clothing business was investigated. In three areas, namely retail, wholesale and clothing manufacturing, the majority of $40(80 \%), 47(94 \%)$ and $43(86 \%)$ respectively (emphasised by the large effect size indices of $\mathbf{w}=$ $0,99,1,29$ and 1,12 respectively) had had no experience. Of the small number who did have some experience, equal numbers had less and more than five years' experience in the above-mentioned areas. This group of respondents had very little experience, which could be a negative factor in their business operations.

\section{The home-based business}

Start-up and functioning The results on this aspect are presented in Table 3.

With respect to the origin of the business Scott (1986) found that $64 \%$ of his respondents had bought or established their businesses themselves. When the respondents in this study were asked how they had acquired their businesses, $49(98 \%)$ said they founded their businesses themselves, and only 1 $(2 \%)$ respondent had bought her business. The nonuniform distribution of the responses is confirmed by the large effect size $(\mathbf{w}=0,96)$.

Reasons for starting a business include the need for additional income, unfavourable economic conditions which place economic pressure on individuals and families and the increasing emancipation of women. This creates a favourable environment for women to start their own businesses. They do so mainly to be their own boss, for the challenge, because it is compatible with their family responsibilities, insufficient opportunities while working for others (Scott, 1986), and to be able to do what they like, to do what they believe in and are good at (Sitterly, 1994:19).

The respondents' reasons for starting the business varied considerably, and they could indicate more than one reason. Forty-eight (96\%) saw the business mainly as an opportunity to earn money, which corresponds with the findings of a study in Bristol (Anderson \& Woodcock, 1996:204) where it was found that businesses are often launched after a personal crisis with financial implications.

In this study more than two thirds of the respondents, namely $35(70 \%)$, believed that a home-based business would be compatible with their family obligations. Kuratko and Hodgetts (1995:651) point out that 
TABLE 2: DEMOGRAPHIC FACTORS OF HOME-BASED BUSINESS OWNERS

\begin{tabular}{|c|c|c|c|}
\hline & & $N(\%)$ & $\begin{array}{c}\text { Effect size } \\
\mathbf{w}\end{array}$ \\
\hline Origin & $\begin{array}{l}\text { Founded themselves } \\
\text { Bought business }\end{array}$ & $\begin{array}{c}49(98 \%) \\
1(2 \%)\end{array}$ & $0,96^{*}$ \\
\hline Reasons for starting & $\begin{array}{l}\text { Wants to be own boss } \\
\text { For the challenge } \\
\text { To earn money } \\
\text { Compatible with family }\end{array}$ & $\begin{array}{l}20(40 \%) \\
33(66 \%) \\
48(96 \%) \\
35(70 \%)\end{array}$ & \\
\hline Start-up capital & $\begin{array}{l}\text { Own capital } \\
\text { Loan }\end{array}$ & $\begin{array}{c}44(88 \%) \\
6(12 \%)\end{array}$ & $0,76^{*}$ \\
\hline Form of business & $\begin{array}{l}\text { Sole proprietorship } \\
\text { Partnership } \\
\text { Close corporation }\end{array}$ & $\begin{array}{c}46(92 \%) \\
3(6 \%) \\
1(2 \%)\end{array}$ & $1,25^{*}$ \\
\hline Age of business & $\begin{array}{l}0-2 \mathrm{yr} \\
3-6 \mathrm{yr} \\
7-15 \mathrm{yr} \\
>15 \mathrm{yr}\end{array}$ & $\begin{array}{c}14(28 \%) \\
12(24 \%) \\
17(34 \%) \\
7(14 \%)\end{array}$ & 0,29 \\
\hline Yearly turnover & $\begin{array}{l}\mathrm{R} 0-\mathrm{R} 100000 \\
\mathrm{R} 100001-\mathrm{R} 200000 \\
\mathrm{R} 200000+ \\
\text { No response }\end{array}$ & $\begin{array}{c}42(84 \%) \\
2(4 \%) \\
1(2 \%) \\
5(10 \%)\end{array}$ & $1,37^{*}$ \\
\hline Employees & $\begin{array}{l}\text { None } \\
1-3 \\
4-6\end{array}$ & $\begin{array}{c}32(64 \%) \\
14(28 \%) \\
4(8 \%)\end{array}$ & $0,70^{*}$ \\
\hline Length of work day & \begin{tabular}{|l}
$<<\mathrm{hrs}$ \\
$8-12 \mathrm{hrs}$ \\
$>12 \mathrm{hrs}$
\end{tabular} & $\begin{array}{l}14(28 \%) \\
26(52 \%) \\
10(20 \%)\end{array}$ & 0,41 \\
\hline Target market & \begin{tabular}{|l} 
None-specific \\
Boutiques
\end{tabular} & $\begin{array}{c}46(92 \%) \\
4(8 \%)\end{array}$ & $0,84^{*}$ \\
\hline
\end{tabular}

${ }^{*} \mathbf{w}>0,5$, indicating a large effect size

changes in our society necessitate dual-income families. However, this caused interrole conflict which could make the worker role and the homemaker role incompatible. In the home-based business, however, where the woman operates in her home environment, the roles could be compatible. In this study $33(66 \%)$ of the respondents started the business as a challenge. Another reason mentioned in the Bristol study (Anderson \& Woodcock, 1996:204) was that 20 (40\%) of the women wanted to be their own boss. Five (10\%) provided additional reasons, for example to enjoy the undertaking, or because of dissatisfaction with a previous occupation, or having moved from a previous location.

Obtaining capital seems to be one of the genderrelated barriers female business owners encounter. Anderson and Woodcock (1996:206) found that there was a general perception among female business owners that bank managers and other lenders did not consider women credible business proprietors. Er- wee (1987) reported that more than $50 \%$ of women entrepreneurs used their own money as initial capital for a business. The start-up costs of home-based businesses vary according to the business type, but some can be launched with very little capital. Beech (1997) as well as Alderman and Cheney (1997) point out that a home business in the USA can be started with as little as $\$ 500$.

In this study 44 women ( $88 \%)(\mathbf{w}=0,76$ indicating a large effect size index) provided their own initial capital, which corresponds with the figures given by Anderson and Woodcock (1996:206). According to these authors $83,7 \%$ of women who started businesses used their personal savings as start-up capital, and in this study 6 women (12\%) acquired loans. The majority, namely 46 (92\%), used R50 000 or less as initial capital, and only $4(8 \%)$ started their businesses with more than R100 000 . The fact that most of these respondents could start their businesses with relatively little initial capital, confirms the previous 
TABLE 4: PROBLEMS EXPERIENCED SINCE THE BUSINESS WAS STARTED

statement that one of the advantages of a homebased business is the small initial capital required.

The South African legal system makes provision for five forms of business, namely sole proprietorship, a partnership, close corporation, company and a business trust, of which the first three are common in home-based businesses. Only the close corporation is a legal person in its own right (Kilian, 1998:59).

Most of these respondents, namely 46 (92\%), were sole proprietors. Three $3(6 \%)$ had concluded a partnership, and $1(2 \%)$ chose a close corporation as her form of business. The large effect size index of $\mathbf{w}=$ 1,25 points to a largely non-uniform distribution of responses.

With respect to the age of the business Kuratko and Hodgetts (1995:648), a long-term study conducted in the USA revealed that fewer than one in four businesses owned by women failed. One of the key reasons cited for the women's success was their management style. They also tended to deal better with people. When Moorman and Halloran (1993:4) looked at both male and female-owned small businesses, the failure rate was found to be more than
$50 \%$ within four years.

In this study 7 (14\%) of the businesses existed for more than 15 years, 17 (34\%) between 7 and 15 years, $12(24 \%)$ for 3 to 6 years and $14(28 \%)$ for less than 2 years. It is clear from these results that $52 \%$ of the businesses survived for 6 years or less. In the USA the national average business failures within the first 6 years is approximately 60\% (Kuratko \& Hodgetts, 1995:648; Timmons, 1994:10).

Although yearly turnover figures in the USA for homebased businesses could not be obtained, known net revenues which were established in a study by Beech (1997) suggest that the yearly turnover is relatively small. In 1996 just more than half of the femaleowned home-based businesses in the USA earned net revenues of less than $\$ 50000$, and only $20 \%$ earned more than $\$ 100000$.

Forty-five of the respondents in this study (90\%) recorded a yearly turnover of R100 000 or less; the rest showed bigger turnovers. Most responses are nonuniformly distributed, as is obvious from the large effect size index $(\mathbf{w}=1,37)$. 
TABLE 4: PROBLEMS EXPERIENCED SINCE THE BUSINESS WAS STARTED

\begin{tabular}{|c|c|c|c|c|c|c|c|}
\hline \multirow[b]{2}{*}{ PROBLEM } & \multicolumn{3}{|c|}{$\begin{array}{l}\text { Extent to which problem was } \\
\text { experienced }^{\star \star}\end{array}$} & \multirow[b]{2}{*}{  } & \multirow[b]{2}{*}{ 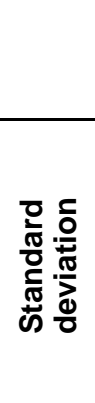 } & \multirow[b]{2}{*}{ 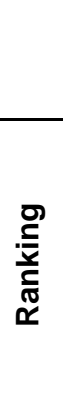 } & \multirow[b]{2}{*}{ 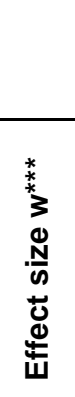 } \\
\hline & 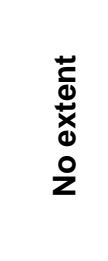 & 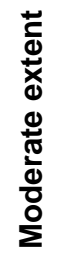 & 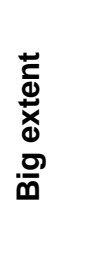 & & & & \\
\hline \multirow{2}{*}{ Obtaining initial capital and credit } & 30 & 17 & 3 & \multirow[b]{2}{*}{1,46} & \multirow[b]{2}{*}{0,61} & \multirow[b]{2}{*}{1} & \multirow[b]{2}{*}{0,66} \\
\hline & 60 & 34 & 6 & & & & \\
\hline \multirow{2}{*}{$\begin{array}{l}\text { Balance between family and } \\
\text { business needs }\end{array}$} & 31 & 17 & 2 & \multirow{2}{*}{1,42} & \multirow{2}{*}{0,57} & \multirow{2}{*}{2} & \multirow{2}{*}{0,71} \\
\hline & 62 & 34 & 4 & & & & \\
\hline \multirow{2}{*}{$\begin{array}{l}\text { Bookkeeping and financial } \\
\text { management }\end{array}$} & & 4 & 6 & \multirow{2}{*}{1,32} & \multirow{2}{*}{0,68} & \multirow{2}{*}{3} & \multirow{2}{*}{0,99} \\
\hline & 80 & 8 & 12 & & & & \\
\hline \multirow{2}{*}{ Advertising and sales promotion } & 40 & 9 & 1 & \multirow[b]{2}{*}{1,22} & \multirow[b]{2}{*}{0,46} & \multirow[b]{2}{*}{4} & \multirow[b]{2}{*}{1,01} \\
\hline & 80 & 18 & 2 & & & & \\
\hline \multirow{2}{*}{ Cash flow } & 45 & 2 & 3 & \multirow[b]{2}{*}{1,16} & \multirow[b]{2}{*}{0,51} & \multirow[b]{2}{*}{5} & \multirow[b]{2}{*}{1,2} \\
\hline & 90 & 4 & 6 & & & & \\
\hline
\end{tabular}

* $\quad$ Average score computed as follows: 1=No extent; 2=Moderate extent; $3=$ Big extent

** Number of respondents given above the dotted line and percentage below the dotted line

*** $\quad$ All effects sizes are $>0,5$, indicating a large effect size 
TABLE 5: SUCCESS FACTORS FOR A
HOME-BASED BUSINESS AS
IDENTIFIED BY PROPRIETORS

\begin{tabular}{|l|c|c|}
\hline \multicolumn{1}{|c|}{ Success factors } & N & $\%$ \\
\hline Good service and personal relation- & & \\
ships & 22 & 44 \\
High quality products & 21 & 42 \\
Self-discipline and diligence & 11 & 22 \\
\hline
\end{tabular}

Women seem to encounter more problems than men in managing their employees. Women generally have to earn credibility among their employees due to a traditional assumption that most men are competent, and until recently this assumption did not extend to women. Some male employees seem unable to accept that their boss is a woman (Anderson \& Woodcock, 1996:207). More than a third of the homebased businesses in the USA are operated by women (Beech, 1997).

Home-based businesses employ fewer workers than most other small businesses, but they do represent substantial job opportunities. There were 20 million home-based businesses in the USA in 1996, and this number grows by $7 \%$ to $8 \%$ every year (Beech, 1997). Watts (1994) reported that there were 32 million workers in home-based businesses in the USA in 1994 and this number has been growing steadily with no slowdown in sight. Thirty-two (64\%) of the respondents in this study did not hire employees. However, $14(28 \%)$ had 1 to 3 employees and $4(8 \%)$ had 4 to 6 employees. The large effect size $(\mathbf{w}=0,70)$ confirms that the response distribution was not uniform.

There is little information about specific working hours per day in home-based businesses, but it is clear that the length of the work day is very flexible. Beech (1997) reports that the female owners of home-based businesses appreciate the advantage of being able to work the hours that suit them and the consequent control they have over their lives. Twenty-six (52\%) of these respondents worked between 8 and 12 hours per day, $14(28 \%)$ worked less than 8 hours per day, and $10(20 \%)$ worked more than 12 hours per day (w $=0,41$, indicating a medium effect size).

The importance of defining a target market as part of a marketing strategy for home-based businesses is emphasised by Alderman and Cheney (1997): "Whichever method you adopt, these general rules will ensure your success. Target, target, target!" Their advice is to make sure that a specific business name is the first that springs to mind and to keep on marketing your product and reminding your customers of what you can offer, even when sales are increasing.

When asked for which target market the respondents manufactured clothing, 46 (92\%) answered that they did not manufacture for any specific target market but on demand or for informal marketplaces such as street markets, and 4 respondents (8\%) manufactured clothes for boutiques. The large effect size index $(\mathbf{w}=$ 0,84 ) indicates a non-uniform response distribution.

\section{Problems encountered by small businesses}

The problems small businesses encountered may be ascribed to various reasons, for example the size of the business. The reasons for the internal problems that are generally listed in the literature are management incompetence, including isufficient managerial information, ineffective planning, insufficient control, unsatisfactory financial management, and ongoing shortage of capital (Zimmerer \& Scarborough, 1996:14); lack of experience, as a good employee does not always possess the required management experience, and insufficient marketing due to overinvolvement in everyday problem situations. This function is neglected at the cost of turnover. The problems experienced by the respondents in this study are listed in Table 4.

The average scores for the problems these respondents experienced indicate that the most serious problem was financial, related to initial capital and credit. This has also been identified as one of the three most important financial problems encountered in femaleowned businesses in the USA (Dollinger, 1995:55). The other two problems this author mentioned were cash flow and financial management, experienced to a lesser degree by the respondents in this study. Anderson and Woodcock (1996:206) sum up the overall situation with respect to financial problems by saying that the general perception regarding capitalisation problems is gender-related, as bank managers sometimes give the impression that they do not see women as credible business owners. In a speech to selfemployed women, a female bank vice president in the USA, Sandra Maltby, revealed that two of the main problems women business owners identified were not being taken seriously and access to capital (Maltby, 1995).

The second most important problem these respondents experienced was maintaining a balance between family and business needs. Kuratko and Hodgetts (1995:651) also mention the work/home role conflict as a problem self-employed women experience. These authors contend that the time pressure of a business bears heavily on the depth of the role conflict. The degree of family support for the woman and her business may also affect the level of tension. Stevenson (1986) points out that men are less inclined to support their self-employed spouses than women are. The results on all five the problems listed in Table 4 reveal a strong non-uniform response distribution, with $\mathbf{w}>0,5$ for all the problem-related variables.

\section{Business success factors}

Alderman and Cheney (1997) summarise the recommendations for success in home-based businesses as 
follows: Get the product right, concentrate on business basics such as a realistic business plan, apply sound financial management, offer better and personal service, concentrate on the target market and be disciplined in balancing work and family life. Other authors (Soldressen et al, 1998) report different business success factors: sufficient operating capital and financial planning, market research, and a wellplanned marketing strategy.

The respondents were asked to identify success factors for a home-based business in view of their experience in their own business. They identified the three factors that are listed in Table 5.

As can be seen from Table 5, good service, personal relationships and high-quality products were deemed the most important success factors. Longenecker et al (1997:3) are also of the opinion that business owners who add an emphasis on superior quality and unquestionable integrity to their attractive products and services are more likely to succeed. Customers like to do business with companies who deliver value for money and who maintain honest relationships. Alderman and Cheney (1997) emphasise the importance of good service by stating that small companies can beat big ones by doing just one thing: offer a better service.

\section{CONCLUSIONS AND RECOMMENDATIONS}

It is clear from the literature that a home-based business holds exceptional advantages for a woman as it offers an opportunity to accommodate both her family and career requirements. Home-based businesses are also more feasible than many other small businesses, as litle initial capital is required, existing structures may be utilised, implying lower overhead costs, and job creation becomes a reality.

This study indicated that more than half the respondents had self-employed parents. Nearly three quarters were married, which probably contributed to their choice of a career. Many grew up in self-employed environments and they probably considered compatibility of their work and married lives advantageous. Only a third had tertiary qualifications, which might, according to Hisrich and Peters (1997:12), limit their business success. A remarkably high $86 \%$ of the respondents had received no formal business training or had no experience in manufacturing clothes - prerequisites recommended in the literature.

Eighty-eight per cent of the respondents had provided their own start-up capital, which provides a link between their financial problems and obtaining capital and credit. A home-based business is within the reach of many people as it can be started with relatively litle capital.

The main reason why the respondents started their businesses seems to be the opportunity to earn money. These businesses survived for longer than home-based businesses in the USA; nearly half survived for six years or longer, and this is encouraging.

It is disturbing that $92 \%$ of the respondents do not manufacture products for a specific target market, as the literature seems to consider this an essential requirement for successful marketing in home-based businesses. The most salient problems seem to be obtaining initial capital and credit, and balancing family and business activities. The most important success factors that were identified were excellent service and interpersonal relations, and high-quality products.

More research is recommended in this field in South Africa, as very little information on this topic is available. Awareness of the feasibility of home-based businesses as a career should be created by disseminating relevant information. There is tremendous potential for starting home-based businesses in South Africa, and the opportunities have by no means been fully utilised. However, an important precondition is sufficient business and skills training.

Home economists have an advantage in this respect, as they are well trained and have various skills from which to choose when they decide to establish a home-based business. As nearly all the respondents looked upon their home-based businesses as an opportunity to earn money, they should be aware that higher education, business training and experience would promote their aim. Another requirement which should not be disregarded is a proper marketing strategy in which targeting should play a prominent role.

\section{REFERENCES}

ALDERMAN, L \& CHENEY, K (1997): Smart ways to make $\$ 100,000$ at home. Mon 26(5):142-156.

ANDERSON, AH \& WOODCOCK, P (1996): Effective entrepreneurship: a skills and activity-based approach. Cambridge, Mass. Blackwell.

BABBIE, E (1995): The practice of social research. 7th ed. Belmont. Wadsworth.

BEECH, WM (1997): Building a successful home-based business. Black Enterp 28(2):29-98.

BOWEN, DD \& HISRICH, RD (1986): The female entrepreneur: a career development perspective. Acad Manage Rev 11(2):393-407.

BUTTNER, EH \& MOORE, DP (1997): Women's organizational exodus to entrepreneurship: self-reported motivations and correlates with success. J Small Bus Manage 35(1):3446.

CLOFED (1996): Directory. Johannesburg. Clothing Federation of South Africa.

COHEN, J (1988): Statistical power analysis for the behavioural sciences. Hillsdale, NJ. Lawrence Erlbaum Associates.

DOLLINGER, MJ (1995): Entrepreneurship: strategies and resources. Burr Ridge, III. Irwin.

EHLERS, MB (1998): Home-based business - future solution for small business? Paper: EBN Conference. Cape Town. November: 1-17.

ERWEE, R (1987): Entrepreneurship as a career option for women: an overview of research. S Afr J Bus Manage 18 (3):152-162.

GRIFFIN, CE (1995): Conference call. Entrep 23 (Nov):48- 
50 . GRIFFIN, CE (1996): Out of the ashes. Entrep 24 (Nov):6668.

HATTEN, TS (1997): Small business: entrepreneurship and beyond. Upper Saddle River, NJ. Prentice Hall.

HISRICH, RD \& BRUSH, C (1984): The woman entrepreneur: management skills and business problems. J Small Bus Manage 22(1):30-37.

HISRICH, RD \& PETERS, MP (1998): Entrepreneurship. Boston. Irwin/McGraw-Hill.

HUYSAMEN, GK (1994): Methodology for the social and behavioural sciences. Halfway House. Southern.

JENNINGS, DF (1994): Multiple perspectives of entrepre neurship: text, readings and cases. Cincinnati, Ohio. South-Western.

KILIAN, P (1998): Forms of business, in Kroon, J. Entrepreneurship: start your own business. Pretoria. Kagiso.

KURATKO, DF \& HODGETTS, RM (1995): Entrepreneurship: a contemporary approach. 3rd ed. Fort Worth. Dryden.

LAMBLING, P \& KUEHL, C (1997): Entrepreneurship. New Jersey. Prentice Hall.

LONGENECKER, JG, MOORE, CW \& PETTY, JW (1997):

Small business management: an entrepreneurial emphasis.

Cincinnati, Ohio. International Thomson. MALTBY, S (1995):

Banks and the woman business owner. Vital Speeches Day 62(6):186-188

MENTOOR, ER (1996): Business affirmative action for small business development in South Africa. Proceedings of 9th Annual Conference of the International Council for Small Business - Southern Africa: 1-20.

MOOLMAN, PL (1992): The nature and essence of entrepreneurship, in Kroon, J \& Moolman, PL. Entrepreneurship. Potchefstroom. Central.

MOORMAN, JW \& HALLORAN, JW (1993): Entrepreneurship. Cincinnati, Ohio. South Western.

MURPHY, KR \& DAVIDSHOFER, CO (1994): Psychological testing: principles and applications. 3rd ed. Englewood Cliffs, NJ. Prentice Hall.

NDU, C (1997): Promoting entrepreneurship in South Africa (with particular emphasis on women entrepreneurs) through financing, training and cultural empowerment. Proceedings of 10th Annual Conference of the Southern African Entrepreneurship and Small Business Association:138-154.

POFELDT, E (1997): The self-made woman. Success 44 (5):36-40.

ROBERTS, LP \& CHRISMAN, JJ (1996): Under one roof: toward a reconciliation of home-based work typologies. J Small Bus Entrep 13(4):18-33.

SCOTT, CE (1986): Why more women are becoming entrepreneurs. J Small Bus Manage 24(4):37-44

SINGER, J (1995): Home pride. Entrep 23(Sep): 46-48

SITTERLY, C (1994): The female entrepreneur - overcoming challenges in the business world. Menlopark. Crisp. SOLDRESSEN, S, FIORITO, SS \& HE, Y (1998): An exploration into home-based businesses: data from textile artists.
J Small Bus Manage 36(2):33-44.

STEVENSON, LA (1986): Against all odds: the entrepre neurship of women. J Small Bus Manage 24(4):30-36.

STEYN, AGW, SMIT, CF, DU TOIT, SHC \& STRASHEIM, C (1994): Modern statistics in practice. Pretoria. Van Schaik. TIMMONS, JA (1994): New venture creation: entrepreneurship for the 21st century. Burr Ridge, III. Irwin.

WATTS, CF (1994): Home is where the business is. Black Enterp 25(4):128-138.

WHITE PAPER ON NATIONAL STRATEGY FOR THE DEVELOPMENT AND PROMOTION OF SMALL BUSINESS IN SOUTH AFRICA (1995): Government Gazette 357(16317). ZIMMERER, TW \& SCARBOROUGH, NM (1996): Entrepreneurship and new venture formation. Upper Saddle River, NJ. Prentice Hall. 